\title{
SISTEM PENGUKURAN KINERJA TERHADAP KINERJA BANK SYARIAH
}

\author{
Mitha Endah Aprilia \\ Jurusan Akuntansi, Universitas Gajayana Malang, \\ Malang, Indonesia
}

email: mitha_endah@unigamalang.ac.id

\begin{abstract}
Abstrak
Penelitian ini bertujuan menguji pengaruh sistem pengukuran kinerja yang terdiri dari sistem pengukuran kinerja strategik dan pengendalian interaktif terhadap kinerja Bank Syariah. Pengumpulan data dilakukan dengan mail survey kepada 50 Bank Syariah di Jawa Timur. Dalam Pelaksanaannya, setiap pengisian kuesioner diwakili oleh manajer operasional Bank Syariah dan diolah dengan menggunakan regresi berganda. Hasil studi menunjukkan bahwa sistem pengukuran kinerja yang terdiri dari sistem pengukuran kinerja strategik dan pengendalian interakti berpengaruh terhadap kinerja bank syariah. Hal ini membuktikan bahwa sistem pengukuran kinerja meningkatkan kualitas informasi manajer dalam menentukan keputusan strategi. Teori sistem pengendalian managemen menjelaskan bahwa adanya sebuah perencanaan, perumusan strategi jangka panjang akan mempengaruhi perkembangan perbankan syariah di masa yang akan datang. Penelitian selanjutnya dapat menambahkan kemampuan perusahaan yang dapat diukur melalui human capital, dimana sumber daya manusia yang kompeten akan mampu meningkatkan kemampuannya dalam memenuhi kebutuhan pasar dan selalu berinovasi.
\end{abstract}

Kata Kunci: Sistem Pengukuran Kinerja Strategik, Pengendalian Interaktif dan Kinerja Bank Syariah.

\begin{abstract}
This study aims to examine the effect of a performance measurement system consisting of a strategic performance measurement system and interactive control on the performance of Islamic Banks. Data collection was carried out by mail survey to 50 Sharia Banks in East Java. In its implementation, each questionnaire was filled in represented by the operational manager of a Sharia Bank and processed using multiple regression. The study results show that the performance measurement system which consists of a strategic performance measurement system and interactive control affects the performance of Islamic banks. This proves that the performance measurement system increases the quality of manager's information in determining strategic decisions. Management control system theory explains that the existence of a plan, long-term strategy formulation will affect the development of Islamic banking in the future. Future studies can add to the company's ability that can be measured through human capital, where competent human resources will be able to improve their ability to meet market needs and always innovate.
\end{abstract}

Keywords: Strategic Performance Measurement System, Interactive Control and Islamic Bank Performance.

\section{Pendahuluan}

Perkembangan Bank syariah tidak terlepas adanya hukum Islam yang melarang bunga dalam semua aspek kegiatan perbankan syariah. Dimana seluruh transaksi dan produknya dioperasionalkan sesuai dengan hukum syariah, yang menyebabkan perbedaan signifikan di banyak kegiatan operasi bank syariah dengan bank konvensional. Pada Proses pendanaan, bank syariah menerapkan profit and loss sharing (PLS) kontrak seperti mudharabah bersama dengan kontrak fee-based seperti wakalah dan wadiah. Sedangkan dalam bidang pembiayaan, bank syariah menerapkan pembiayaan berbasis utang, yang biasanya disebut kontrak pertukaran, seperti murabahah, mudharabah dan musharakah (Pepsky, 2012). Namun, pada kenyataanya bank syariah kurang berkembang di indonesia dikarenakan 
persaingan di industri jasa keuangan yang berpengaruh terhadap kinerja perbankan syariah dan beberapa masalah seperti sumber daya manusia, teknologi dan informasi serta keterbatasan modal dari perbankan itu sendiri (infobanknews, 06 januari 2016). Sehingga perlunya menerapkan pengendalian mangemen di dalam organisasi bank syariah.

Beberapa peneliti setuju bahwa penerapan sistem pengendalian managemen pada bank syariah akan meningkatkan kualitas informasi yang di dapatkan (Thuy., 2019) Informasi yang didapatkan dari investor/pemberi dana ditindaklanjuti oleh manajemen/penerima dana berdasarkan prosedur operasional perbankan. Pengendalian manajemen merupakan langkah awal bagi manajemen untuk berperan aktif dalam meningkatkan mutu pelayanannnya. Untuk meningkatkan profit loss sharing, perusahaan perlu melakukan sistem pengendalian managemen, sehingga adanya sinergi dari seluruh manajemen untuk melakukan perubahan dengan adanya strategi yang baru. Dengan demikian, keberadaaan sistem pengendalian manajemen menjadi kajian yang menarik dalam dunia perbankan (Henri, 2006)

Sistem pengendalian manajemen telah banyak dibuktikan kaitannya dalam merancang strategi baru (Henri, 2006; steven et al.,2013; Thuy., 2019; josep.B et al., 2019). Dalam studi ini, sistem pengendalian managemen memahami proses manajemen strategis yang menindaklanjuti melalui perencanaan, perumusan dan evaluasi kinerja melalui perbaikan dan tindakan yang akan dilakukan selanjutnya (josep.B et al., 2019). Hasil perencanaan dan pengendalian memberikan informasi bagi manajemen untuk membuka kemungkinan peluang baru untuk berinteraksi dengan lingkungannya. Menurut Simons (1994), penggunaan pengendalian interaktif dan sistem pengukuran kinerja strategik untuk mengangkap informasi, ketika dilakukan dengan pengawasan, perdebatan yang memungkinkan proses pembelajaran akan terjadi yang pada akhirnya meningkatkan kinerja perusahaan. walaupun demikian, masih adanya perbedaan pendapat mengenai hubungan antara sistem pengendalian manajemen dan strategi. (Henri,2006).

Strategi adalah suatu cara bagaimana perusahaan mampu menciptakan kemampuan organisasi dalam memilih pangsa pasarnya. Salah satunya, strategi dijelaskan oleh pengendalian interaktif dan sistem pengukuran kinerja strategik yang memaparkan bahwa ukuran finansial dan nonfinansial merupakan seperangkat ukuran kinerja (Chenhall, 2005). Sistem ini mengintegrasikan strategi jangka panjang untuk tujuan operasional, memberikan langkah-langkah kinerja pada keuangan dan non keuangan, menyediakan perencanaan untuk tujuan organisasi dan memberikan hubungan kausal antara tujuan dan langkahlangkah kinerja (Jean., 2006). Pengendalian interaktif memiliki peran yang sama pentingnya dalam meningkatkan kinerja bank islam yaitu ketika manajer bisnis menggunakan prosedur perencanaan dan pengendalian aktif untuk memantau kegiatan pengambilan keputusan langsung dari bawahan (Henri,2006). Interaksi yang terjadi difokuskan pada peran sistem pengendalian manajemen untuk mengimplementasi strategi. Oleh karena itu, intervensi ini memberikan kesempatan bagi manajemen puncak untuk berkomunikasi secara aktif yang menuntut perhatian dari seluruh bawahan yang beroperasi di semua tingkat perusahaan dan informasi yang didapatkan memberikan dasar untuk berpikir strategi jangka panjang.

Para peneliti menyatakan bahwa sistem pengukuran kinerja strategik dan pengendalian interaktif berhubungan positif dengan kinerja organisasi (Jessica., 2019; juha et al., 2011; adi et al., 2011; steven et al.,2013; Thuy., 2019; josep.B et al., 2019; mark ., 2013;candice., 2017; jean., 2006; david., 2019;christoper.D.,2003; Laurie et al., 2009; Benedik.M.,Stewens.S.,Widener.K.,C.2020). Perusahaan yang menggunakan sistem pengukuran kinerja strategik cenderung lebih meningkat dibangingkan perusahaan yang tidak menggunakan sitem pengukuran kinerja strategik. Kontrol interaktif yang tinggi meningkatkan komunikasi yang lebih baik kepada seluruh pihak managemen (Henri 2006).

Penelitian ini merupakan pengembangan dari penelitian Henri (2006) yang menggunakan sistem pengukuran kinerja dalam meningkatkan kinerja organisasi di perusahaan manufaktur. Berbeda dengan penelitian Henri (2006), penelitian ini menguji pada perusahaan bank syariah yang berada di Jawa Timur, karena diketahui adanya perbedaan kebijakan dan strategi perusahaan dalam mengembangkan organisansinya Sehingga tujuan penelitian ini adalah ingin mengetahui bagaimana peran dari sistem 
pengukuran kinerja strategik dan pengendalian intraktif dalam mempengaruhi keputusan manajemen.

\section{Metode}

Dalam metode penelitian ini, peneliti melakukan survey pada Bank Syariah di Jawa Timur. Metode sensus digunakan peneliti, dikarenakan jumlah sampelnya yang relatif sedikit yaitu 50 Bank Syariah di Jawa Timur, maka seluruhnya akan digunakan sebagai smpel penelitian dan setiap Bank diwakili oleh manajer operasional, karena mengetahui seluruh aktivitas proses organisasi yang dilakukan di dalam perusahaan. Dalam pengumpulan data menggunakan mail survey, karena dapat menjangkau wilayah geografis dan responden merasa nyawan dalam menjawab pertanyaannya (Sekaran dan Bougie, 2010:197).

Sebelum kuesioner disebar, penelitian ini melakukan uji instrumen dalam penelitian ini dengan menguji reabilitas dan validitas dari item pertanyaan, karena penelitian sebelumnya dilakukan di luar negeri. Oleh karena itu, peneliti perlu menguji kembali yang diuji validitas dan reliabilitasnya kembali mengingat adanya perbedaan tempat, waktu dan responden yang akan mengisi kuesioner ini.

Metode analisis yang digunakan dalam penelitian ini adalah regresi berganda dengan menggunakan program spss untuk menguji hipotesis yang diajukan. Dalam analisis regresi, selain mengukur kekuatan hubungan antara dua variabel atau lebih, juga menunjukkan arah hubungan antara variabel dependen dengan variabel independen (Ghozali, 2011:96). Regresi berganda (multiple regression) diterapkan untuk memecahkan kasus yang memiliki satu variabel dependen dengan beberapa atau lebih dari satu variabel independen. Pada penelitian ini, peneliti menguji pengaruh $\mathrm{Y} 1$ terhadap $\mathrm{x} 1$ dan $\mathrm{x} 2$ dengan menggunakan analisis regresi berganda sebagai berikut:

$Y=a+b_{1} X_{1}+b_{2} X_{2}+\ldots .+b_{n} X_{n}+\varepsilon(1)$

Instrumen yang digunakan untuk mengukur konstruk dalam studi ini adalah instrumen yang pernah digunakan dalam penelitian-penelitian sebelumnya yaitu; chenhall 2005; Suardika, 2011. Konstruk penelitian ini terdiri dari variabel kinerja organisasi (variabel dependen) menilai hasil akhir dari aktivitas usaha yang dilakukan oleh bank syariah (bank islam) dalam operasional yang dilaksanakan. Variabel sistem pengukuran kinerja strategik (variabel independe) mendefinisikan visi dan misi organisasi dalam melakasanakan tujuan perusahaan, khususnya meningkatkan ukuran keuangan dan non keuangan dan pengendalian interaktif (variabel independen) berfungsi komunikasi interaktif yang dilakukan oleh karyawan kepada kelompok organisasi/Atasan sebagai motivasi karyawan terhadap tindakan organisasi yang sejalan dengan tujuan perusahaan.

\section{Hasil Dan Pembahasan}

Sebelum melakukan penyebaran data sesungguhnya dilapangan, maka terlebih dahulu peneliti menguji validitas dan reliabilitas dari item-item pertanyaan kuesioner yang akan digunakan pada penelitian ini. Hal ini menjadi penting, karena peneliti mengambil item pertanyaan dari penelitian asing, sehingga harus dilakukan pengujian terhadap item pertanyaan. Ada beberapa tahapan yang dilakukan peneliti, pertama peneliti mentranslate item pertanyaan ke dalam bahasa Indonesia melalui Lembaga Bahasa Brawijaya Malang, kedua peneliti menguji sampel pertanyaan melalui 15 responden mahasiswa S2 yang mengambil matkul Akuntansi Manageman Lanjutan, karena mahasiswa tersebut dianggap mampu memahami sistem pengukuran kinejra, ketiga menyebarkan kuesioner kepada pihak Manager Oeprasional Bank Syariah. Namun sebelum Kuesioner disebar, peneliti memastikan terlebih dahulu dengan melakukan via telepon kepada Human managemen Resources bahwa peneltian ini bisa dilakukan di Bank Syariah, setelah mendapatkan konfirmasi tersebut.

Hal ini dijelaskan oleh Tabel 1 yang menguji validitas dan reabilitas dari item pertanyaan yang berikan: 
Tabel 1. Reliabilitas dan Validitas

\begin{tabular}{lllll} 
Variabel & $\begin{array}{l}\text { Corrected item } \\
\text { total collection }\end{array}$ & $\begin{array}{l}\text { Cronbach's } \\
\text { Alpha }\end{array}$ & $\begin{array}{l}\text { Cronbach's Alpha } \\
\text { Based on } \\
\text { Standardized Items }\end{array}$ & N of Items \\
\hline $\mathrm{Y}$ & 0,608 & 0.535 & 0.531 & 6 \\
$\mathrm{X} 1$ & 0,755 & & & 7 \\
$\mathrm{X} 2$ & & 0.744 & 0.751 & 7 \\
\hline
\end{tabular}

Berdasarkan tabel 1 menunjukkan bahwa nilai alpha sudah mencapai 0,50-0,70 maka dapat dikatakan reliabel dan dapat dilihat nilai tiap-tiap item sebaiknya $\geq 0.40$ sehingga membuktikan bahwa item tersebut dapat dikatakan mempunyai reliabilitas konsistensi Internal (Gozali, 2011). sedangkan uji validitas dapat dilihat dari corrected item yang berada diantra 0,50-0,70, sehingga dapat dikatakan seluruh item valid dan reliabel. Hal ini menunjukkan bahwa setiap item pertanyan yang diberikan sudah memberikan repon yang baik dan bisa didistribusikan kepada manager Operasional Bank Syariah, dimana item pertanyaan ini lebih berfokus pada pengembangan jangka panjang perusahaan dan sistem pengukuran kinerja memberikan informasi bagi managemen terkait kemampuan perusahaan dalam melakukan strategi dan memaksimalkan kualitas informasi yang didapatkan sehingga interaksi yang terjalin di antara organisasi akan memberikan masukan bagi manajemen untuk meningkatkan kemampuan sumber daya sehingga dapat meningkatkan kinerja organisasi bank Islam dan efektif bagi manajemen untuk digunakan sebagai pilihan strategis seperti sistem pengukuran kinerja strategik, pengendalian interaktif dan kinerja Bank Syariah.

Hasil penelitian ini sejalan dengan teori sistem pengendalian managemen yang meliputi kegiatan perencanaan operasional perusahaan. Konsep sistem pengendalian manajemen merupakan sebuah perencanaan yang sistemastik di dalam organisasi yang terdiri dari perumusan, perencanaan dan pelaksanan. Sehingga sistem pengendalian managemen merupakan suatu proses perumusan, perencanaan dan pengembangan dari strategi jangka panjang yang dapat memberikan arahan terhadap wewenang tiap individu dalam pencapaian tujuannya. Hal ini ditunjukkan dari hasil penelitian yang dilakukan untuk mengukur keterhubungan dari sistem pengukuran kinerja yang terdiri dari sistem pengukuran kinerja terhadap kinerja Bank Syariah pada Tabel 2.

Pada pengujian pertama menunjukkan konstruk sistem pengukuran kinerja strategik berpengaruh terhadap kineja bank syariah, sehingga hipotesis 1 diterima. Hasil penelitian ini menunjukkan bahwa adanya pengaruh sistem pengukuran kinerja strategik tehadap kinerja Bank Syariah menjadi suatu indikasi bahwa informasi memiliki peran yang penting bagi perusahaan untuk mempengaruhi manajemen dalam mengambil keputusan strategi. Sistem pengukuran kinerja strategik menerjemahkan strategi ke dalam ukuran keuangan dan non keuangan, sehingga memudahkan manajemen untuk menjaga keselarasan antara tujuan organisasi dan kegiatan operasional. Adanya sistem ini dipercaya memberikan gambaran bagi manajemen senior untuk mendapatkan informasi mengenai kondisi perusahaan melalui ukuran-ukuran yang mewakili strategi perusahaan.

Tabel 2. Pengaruh Hipotesis

\begin{tabular}{|c|c|c|c|c|c|}
\hline Variabel & $B$ & Standar error & $\begin{array}{l}\text { Standardized } \\
\text { Coefficients }\end{array}$ & Uji t & Significant \\
\hline$X 1->$ & 0,142 & 0.074 & 0.304 & 1.924 & 0.063 \\
\hline$X 2->Y$ & 0.126 & 0.071 & 0.281 & 1.784 & 0.084 \\
\hline
\end{tabular}

Penelitian yang relevan dilakukan chenall (2005) yang mengasumsikan sistem pengukuran yang bersifat strategis memberikan pendekatan yang lebih terintegrasi untuk 
pelanggan dan visi perusahaan. Pentingnya sistem pengukuran kinerja strategik sebagai elemen penting dari sistem pengendalian manajemen, karena mencerminkan peran paling penting dari akuntansi sebagai sistem pengukuran. Temuan hasil penelitian ini sejalan dengan Henri (2006) yang menunjukkan bahwa sistem pengukuran kinerja akan meningkatkan kinerja perusahaan baik dari mutu atau layanan pada pelanggan, seperti informasi terhadap kebutuhan pelanggan (Chenhall 2005; Eisenhardt dan Martin 2000). Hasil penelitian ini juga memberikan ruang ketika sistem pengukuran kinerja strategik didukung dengan kemampuan perushaan untuk belajar dan inovasi maka sistem pengukuran kinerja strategik dapat memberikan solusi terhadap masalah yang ditimbulkan dari ketidakpastian untuk beradaptasi dengan perubahan.

Pada pengujian ke 2 yang menunjukkan konstruk pengendalian interaktif terhadap kinerja bank syariah dan hipotesis 2 diterima. Hasil penelitian ini menunjukkan pengendalian interaktif yang tinggi di bank syariah memfasilitasi manajemen untuk melakukan pengendalian dan menindaklanjuti kegiatan di organisasi melalui indikator keterlibatan manajemen, kualitas staf, perhatian manajer operasional, proses interaksi dari keterlibatan manajer memberikan respon yang cukup baik oleh manajer sebagai aplikasi dalam memberikan komunikasi yang aktif untuk membantu pelaksanaan strategi dan informasi yang berperan dalam memberikan pengetahuan manajemen untuk memilih strategi yang berguna bagi perusahaan (vicky et al., 2011; Angela.L. 2019). Proses pengendalian interaktif memberikan rangsangan kepada manajer untuk berpikir kritis dalam mengembangkan ide-ide kreativitas sebagai kekuatan aktif yang mendorong manajemen menemukan peluang-peluang baru. Komunikasi yang tinggi dipercayai dapat membantu manajemen untuk melakukan pengawasan terhadap kinerja organisasi secara menyeluruh.

Artinya adanya dialog dan debat organisasi mendorong pertukaran informasi pada pengetahuan, sehingga memunculkan tindakan strategi. Hal ini juga didukung dengan penelitian Henri (2006) Dalam meningkatan kinerja organisasi, managemen meningkatkan rangsangan komunikasi sebagai sistem kontrol. Adanya tuntutan dari perusaahaan untuk meningakatkan laba, maka manajer perlu melakukan pengendalian yang menyeluruh terhadap kinerja seluruh organisasi guna mendorong pertukaran informasi, sehingga memunculkan tindakan strategi. Menurut Henri (2006) menggunakan pengendalian interaktif merupakan kekuatan penyeimbang yang digunakan untuk menyeimbangkan dialog strategis. Oleh karena itu, temuannya pengendalian interaktif menuntut transparasi atas informas yang berkualitas untuk menindaklanjuti dan mengaplikasikannya dalam bentuk strategi. Beberapa hasil penelitian seperti yang dilakukan oleh (Henri, 2006; Chenhall, 2005; Martin et al., 2012; vicky et al., 2011; Jeff et al., 2020) menunjukkan pengaruh yang positif antara pengendalian interaktif terhadap kinerja organisasi. Adanya teori sistem pengendalian managemen memberikan kesempatan organisasi untuk mengatasi ketidakpastian yang dihadapi oleh manajemen, serta memotivasi manajemen untuk melakukan perbaikan.

\section{Kesimpulan dan Saran}

Hasil penelitian menyimpulkan bahwa sistem pengukuran kinerja berpengaruh terhadap kinerja Bank Syariah. Hal ini mengindikasikan sistem pengukuran kinerja mampu memfasilitasi organisasi pada implementasi strategi yang dipilih dengan tindakan evaluasi kinerja dan memberikan andil dalam meningkatkan strategi jangka panjang. Hasil penelitian ini memperkuat teori sistem pengendalian managemen yang berfokus pada organisasi internal perusahaan sebagai kumpulan sumber daya. Artinya, ketika sistem dan strategi saling terkait aktivitas bersama, maka akan saling melengkapi yang berpotensi mendapatkan keuntungan yang berkelanjutan.

Pengaruh yang paling dominan adalah sistem pengendalian interaktif terhadap kinerja bank islam yang membuktikan bahwa keterlibatan efektivitas manajemen, kualitas staf, manajer operasional, perhatian manajemen, proses interaksi dan keterlibatan manajer akan meningkatkan interaksi yang tinggi terhadap pengawasan yang dilakukan manajemen terhadap proses organisasi. Interaksi yang tinggi memberikan kesempatan bagi manajemen puncak untuk berkomunikasi secara aktif dan informasi pengendalian managemen juga 
memberikan dasar untuk memikirkan strategi. Manajer menggunakan pengendalian interaktif untuk mempengaruhi dan membimbing proses belajar untuk memahami bahwa ide-ide individual dan inisiatif akan muncul dari waktu ke waktu

Penelitian selanjutnya dapat menambahkan kemampuan perusahaan yang dapat diukur melalu human capital, dimana sumber daya manusia yang kompeten akan mampu meningkatkan kemampuannya dalam memenuhi kebutuhan pasar (Mark et al.,2013; Moeheriono, 2009:222).

\section{Daftar Pustaka}

Angela.L. 2019. "Enhancing and enabling management control systems through information technology: The essential roles of internal transparency and global transparency". International journal of accounting information systems, vol 33 pp 16-31

Adi.M.,Vernon.J.,Richardson.,Juan., Rodney.E. 2011."Returns to IT excellence: Evidence from financial performance around information technology excellence awards" International journal of accounting information systems, Vol 12.Issue 3 pp 189-205

Benedik.M.,Stewens.S.,Widener.K.,C.2020."The role of diagnostic and interactive control uses in innovation". Accounting, Organizations and Society Volume 80, January 2020, 101078

Chenhall, R.H. 2005. "Integrative strategic performance measurement systems, strategic alignment of manufacturing, learning and strategic outcomes: An exploratory study". Accounting, Organization and Society 30: 395-422.

Candice T.Hux. 2017."Use of specialists on audit engagements: A research synthesis and directions for future research"Journal of Accounting Literature.Volume 39, December 2017, Pages 23-51

Christopher.D.,David.F.,Taylor.R.2003.“Performance implications of strategic performance measurement in financial services firms"Accounting, Organizations and Society. Volume 28, Issues 7-8, Pages 715-741

David.S.B.,Josep.B.,Breda.S,.2019."Performance measurement systems as generators of cognitive conflict in ambidextrous firms"Accounting, Organizations and Society. Volume 72, January 2019, Pages 21-37

Eisenhardt, K.M. dan Martin, J.A. 2000. “Dynamic capabilities: What are they?".Strategic Management Journal 21: 1105-21

Edson, P.L, Sergio E, G. C. Jannis dan J. Angelis. 2009. "Strategic performance measurement systems: a discussion about their roles". Measuring Business Excellence, Vol. 13 Iss 3 pp. 39 - 48

Ghozali, Imam. 2011. Aplikasi Analisis Multivariate Dengan Program SPSS. Semarang : BP Universitas Diponegoro

Henri, J.F. 2006. "Management control system and strategy: A resource-based perspective". Accounting, Organizations and Society 31: 529-558.

Hundayani, A. 2009. "Hubungan Sistem Pengendalian Manajemen dan Kinerja Pembiayaan Bagi Hasil serta Kinerja Bank Islam di Indonesia". Volume 7, Nomor 1 ISSN 1693-4296

Juha.P.,Ekki.L.,Hanna.S. 2011.“Impact of enterprise resource planning systems on management control systems and firm performance" International journal of accounting information systems, vol 12 Isusue 1 pp 20-39

Jeff. R., Vicky.A., Steven.G. 2020."Synthesizing enterprise data to strategically align performance: The intentionality of strategy surrogation ". International Journal of Accounting Information Systems, Vol. 36, March 2020, 100444 
Jessical.L.,Mohammd.Z.,Habib.,Mahama.,Steven.G. 2014.“Enablers of top management team support for integrated management control systems innovations". International journal of accounting information systems, vol 15.Issue 1 pp 1-25

Josep.B.,Anne.K.,Paola.M., 2019."Coercive, enabling, diagnostic, and interactive control: Untangling the threads of their connections".Journal of Accounting Literature. Vol 43 pp 124-144

Laurie.L.B.,Christine.A.,Sally k.Widener,. 2009. "A path model examining the relations among strategic performance measurement system characteristics, organizational justice, and extra- and in-role performance" Accounting, Organizations and Society Volume 34, Issues 3-4, Pages 305-321

Mark.C.R.2013."Multinational transfer pricing: A transaction cost and resource based view".Journal of Accounting Literature.Volume 31, Issue 1, July 2013, Pages 31-48

Mark L. Lengnick-Hall, C. A. Lengnick-Hall, Leticia S. Andrade dan B. Drake. 2009 Strategic human resource management: The evolution of the field.Human Resource Management Review 19:64-85.

Martin.A,Christian.H \& Thomas.R. 2012."Performance-measurement system design and functional strategic decision influence: The role of performance-measure properties" Accounting,Organizations and Society, Vol 37: Iss 7 pp.445-460

Pepsky. T.B. 2012. "Development, Social Change, and Islamic Finance in Contemporary Indonesia". World Development Vol. 41, pp. 157-167, 2012

Sekaran, Uma dan Roger Bougie. 2010, Research Method for Business, Fifth Edition, USA: John Wiley and Sons, Inc

Suardika, I.N. 2011. Integrasi sumber daya strategis, orientasi kewirausahaan dan dinamika lingkungan sebagai bisnis strategi bersaing serta pengaruh Terhadap Kinerja Usaha (Studi pada Usaha kecil Menengah di Bali). Universitas Brawijaya. PDIM Disertasi tidak diterbitkan.

Steven.G.,Vicky.A. 2013."Focus group methods: Using interactive and nominal groups to explore emerging technology-driven phenomena in accounting and information systems" International journal of accounting information systems, Vol 14. Issue 3 pp 81 88

Thuy.Duong.Oeste .2019. "The controlling profession in the digital age: Understanding the impact of digitisation on the controller's job roles, skills and competences" International journal of accounting information systems, Vol 35.

Vicky. A.,Tanya.B.,Joseph., Steven. 2011. "The role of strategic enterprise risk management and organizational flexibility in easing new regulatory compliance". International journal of accounting information systems, vol 12,September 2011 pp.171-188 